\title{
KONSERVANTŲ VARTOJIMO KOSMETINĖJE PUDROJE BŪTINUMAS
}

\author{
Diana Barragan Ferrer', Jesus Manuel Barragan Ferrer ${ }^{2}$ \\ ${ }^{1}$ Kauno kolegijos Medicinos fakultetas, ${ }^{2}$ Kauno technologijos universiteto \\ Chemines technologijos fakultetas
}

\begin{abstract}
Raktažodžiai: kosmetinè pudra, konservantai, drẻgmès kiekis.

Santrauka

Kosmetikos produktuose vis dažniau atsisakoma konservantų naudojimo dẻl jų kenksmingo poveikio sveikatai. Šio tyrimo tikslas nustatyti konservantu naudojimo būtinumą kosmetinejje pudroje, kurioje nèra vandens. Tyrimo metu buvo analizuojamos kosmetinès pudros su konservantu ir be jo bei nustatoma, ar jos abi atitinka HN-64 reikalavimus. Kosmetiniu pudrų kokybei nustatyti buvo įvertintas drègmès kiekis, mikroorganizmų skaičius bei konservanto įtaka mikroorganizmų skaičiui. Iš gautų rezultatų buvo nustatyta, kad tinkamai parinkus kosmetinès pudros ingredientus, nepalankius mikroorganizmų augimui, galima atsisakyti konservantų naudojimo šiame produkte.
\end{abstract}

\section{Ivadas}

Konservantai i kosmetikos gaminius dedami siekiant išvengti jų mikrobinio užterštumo gamybos bei vartojimo metu [1-2]. Šios medžiagos nedideliais kiekiais panaudotos gaminyje pasižymi bakteriocidinèmis ir fungicidinėmis savybėmis [3-4]. Konservantai veikia mikroorganizmus skirtingai: sunaikina ląstelių membranas arba keičia fermentų aktyvumą ir baltymo sintezę mikroorganizmuose [5-6]. Konservantai būna natūralūs, išskirti iš augalų, bet jie yra silpni, todèl retai naudojami kosmetikos gaminiuose. Populiariausi yra sintetiniai konservantai, kuriu aktyvumas ženkliai didesnis, bet ir šalutinis efektas pasireiškia dažniau [2-4].

Pagrindinès bakterijų dauginimosi, pelèsių ir puvimo atsiradimo salygos yra vanduo, energija ir maistinga medžiaga, kuri yra beveik visuose kosmetikos produktuose. Šie produktai turi azotą ir angli, taip pat mineralines medžiagas ir vitaminus, su atitinkamu deguonies kiekiu. Dèl šios priežasties daugeliui iš jų reikia konservantų. Tačiau, reikia nepamiršti, kad kosmetika naudojama dèl estetiniu priežasčių ir neturi sukelti jokių pavojų vartotojo sveikatai. Kita vertus, konservantai gali sudirginti odą, todèl reikia atsižvelgti ị konservantų efektyvumą ir poveikị odai [1-3]. Konservantai yra naudojami tada, kai gaminys emulsijos tipo, gaminio ingredientai, kurie gali būti kaip maistinga medžiaga mikroorganizmams, tinkamas $\mathrm{pH}$ mikroorganizmų dauginimuisi ir kt. [2].

Per paskutinį dešimtmetị vis daugiau žmonių skundžiasi jautria oda, todèl jie iš kosmetikos gamintojų reikalauja gaminių, kuriuose nebūtų konservantų. Gaminant produktus, kuriuose nèra vandens, galima parinkti tokią produkto sudètí, kad būtų atsisakyta konservantų naudojimo. Taip pat norint išvengti konservanto naudojimo, galima taikyti sterilu gamybos būdą. Tokiu atveju turi būti sterilizuojama žaliava, bet šis būdas netinka medžiagoms, kurios praranda savo savybes aukštoje temperatūroje. Galima sterilizuoti ir jau pagamintą produktą, tačiau šis sterilus produktas gali būti užteršiamas vartotojo, netinkamai jị naudojant. Visi šie išvardinti būdai leistų atsisakyti konservantų naudojimo, tačiau sterilizacija ženkliai padidintų produktų kainą, todèl efektyviau būtų tinkamai parinkti produkto ingredientus, kurie nèra palankūs mikroorganizmų dauginimuisi; tyrime buvo pasirinktos dvi kosmetinès pudros, kurių sudètyje nèra palankios terpès mikroorganizmų dauginimuisi, tačiau vienoje iš jų yra naudojamas konservantas, o kitoje ne.

Tyrimo tikslas - nustatyti konservantų būtinumą kosmetineje pudroje.

\section{Tyrimo objektas ir metodika}

Tiriamajam darbui buvo pasirinktos dvi kosmetinès pudros, viena su konservuojančia medžiaga etilo parabenu, o kita be jos.

Kosmetinės pudros kokybės parametrams ịvertinti buvo nustatomas drègmès kiekis džiovinimo metodu. Kosmetinè pudra išdžiovinama atmosferos slègyje iki pastovios masès, džiovinimo spintoje esant $105 \pm 1{ }^{\circ} \mathrm{C}$ temperatūrai.

Kosmetinès pudros mikrobiologiniams rodikliams ivvertinti buvo nustatomas bendras heterotrofinių bakteriju skaičius. Bandiniai inokuliuojami ì agarizuotą mitybinę 
terpę giluminiu būdu. Mielių ir pelèsinių grybų nustatymui bandiniai sẻjami paviršiniu būdu ị agarizuotą terpę. Rezultatai pateikiami kaip kolonijas sudarančių vienetų skaičius (KSV) $1 \mathrm{~g}$ bandinio, pagal skaičiavimo formulę $\mathrm{M}=(\mathrm{a} \times$ $\left.10^{\mathrm{n}}\right) / \mathrm{V}$, kur a-vidutinis kolonijų, išaugusių Petri lèkštelëje, skaičius; 10-skiedimo koeficientas; n- skiedimo laipsnis; V-medžiagos kiekis g.

Oro mikrobinis užterštumas buvo nustatytas sedimentacijos būdu. Išaugusios kolonijos buvo skaičiuojamos pagal formulę: $\lambda=(\mathrm{A} \times 10 \times 5 \times 100) /(\mathrm{B} \times \mathrm{t})$, kur A-kolonijų skaičius lèkštelèje (KSV); B-lèkštelès plotas $\left(\mathrm{cm}^{2}\right)$; t- ekspozicijos trukmè (min.); 10-oro tūris, išreikštas $\left(\mathrm{m}^{3}\right)$; 100-lèkštelès plotas $\left(\mathrm{cm}^{2}\right)$.

\section{Tyrimo rezultatai}

Pudros drègmès kiekio nustatymas. Šiame eksperimente buvo tirtos dvi pudros, viena su konservuojančia medžiaga etilo parabentu, kita be jos (1 pav.).

Drègmès kiekio dinamika kosmetinèje pudroje pateikta 1 pav. Šio tyrimo tikslas buvo nustatyti, ar pudroje esantis drègmès kiekis yra palankus mikroorganizmų dauginimuisi, kadangi apie 75-90 \% mikroorganizmo ląstelès sudaro vanduo [7], todèl jų augimui nuolat reikia vandens. Su

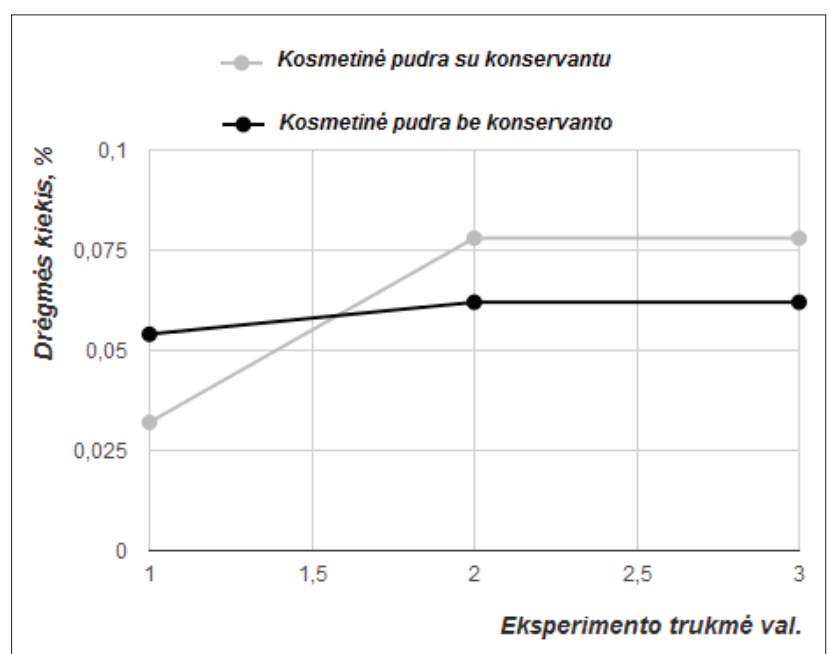

1 pav. Drègmès kiekio kitimas kosmetinėje pudroje

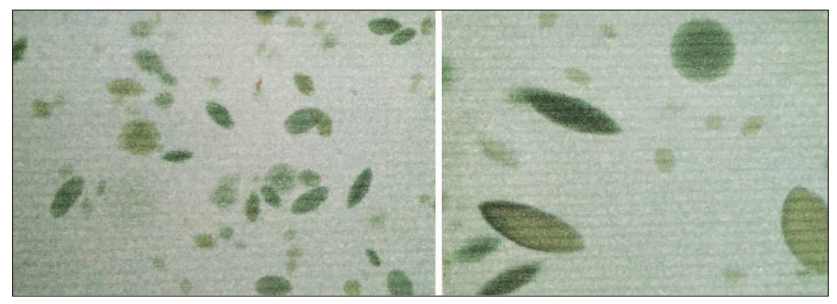

2 pav. Heterotrofinių bakterijų kolonijos vandeniu i ląstelę patenka ištirpusios maisto medžiagos ir šalinami medžiagų apykaitos produktai. Kita vertus, ne visi mikroorganizmai vienodai jautrūs vandens trūkumui. Daugumos bakterijų veikla sustoja, kai sumažeja terpejje vandens iki 20-30\%, o mikromicetu - iki 10-15\% [8].

Iš gautų rezultatų matome, kad tirtų kosmetinių pudrų drègmė yra mažesnè nei $0,1 \%$, todèl galime daryti prielaidą, kad tokioje aplinkoje mikroorganizmai negalès augti, nes bus sutrikdomi mikrobinių ląstelių medžiagos apykaitos procesai. Žinoma, kad minimalus drègmès kiekis heterotrofiniams mikroorganizmams augti yra $20 \%$, o mieliniams grybams - $15 \%$ [8-10]. Iš gautų rezultatų galime daryti prielaidą, kad tirtos kosmetinès pudros gali būti be konservuojančių medžiagų dẻl mažo kiekio vandens, tačiau norint tai patvirtinti reikia ịvertinti, ar pudrų sudètis yra palanki mikroorganizmo dauginimuisi.

Mikroorganizmų skaičius kosmetinėje pudroje. Eksperimento tikslas - nustatyti mikroorganizmų kieki kosmetineje pudroje. Norint ịvertinti mikroorganizmų medžiagų apykaitos, dauginimosi, augimo procesus ir maisto medžiagų poreikị, būtina žinoti jų ląstelių cheminę sudètị. Mikrobinè ląstelè susideda iš vandens, organinių ir mineralinių medžiagų. Pagal Europos Sajungos ir Lietuvos higienos normos HN 64-2001 reikalavimus [11] Lietuvoje gaminamos ir parduodamos kosmetinès pudros mikrobinis užterštumas, bendras heterotrofinių bakterijų skaičius negali viršyti $500 \mathrm{KSV} / 1 \mathrm{~g}$. Atlikus tyrimus nustateme, kad kosmetinèje pudroje su konservuojančia medžiaga bendras heterotrofinių bakterijų skaičius $322 \pm 16 \mathrm{KSV} / 1 \mathrm{~g}$, kita vertus, kosmetinèje pudroje be konservuojančios medžiagos šių bakterijų skaičius buvo didesnis, tai yra $417 \pm 15$

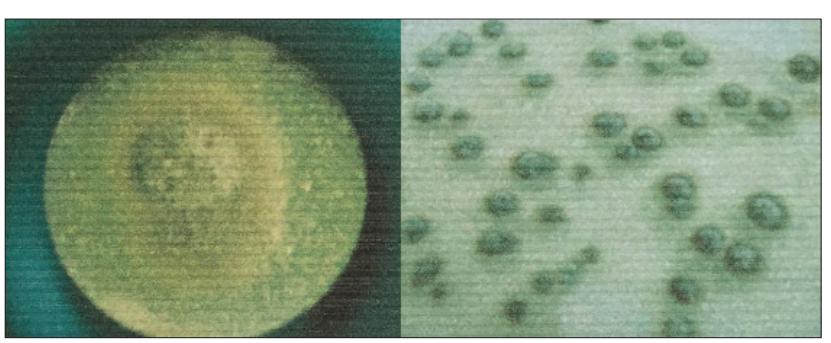

3 pav. Penicillium genties pelèsinių grybų kolonijos

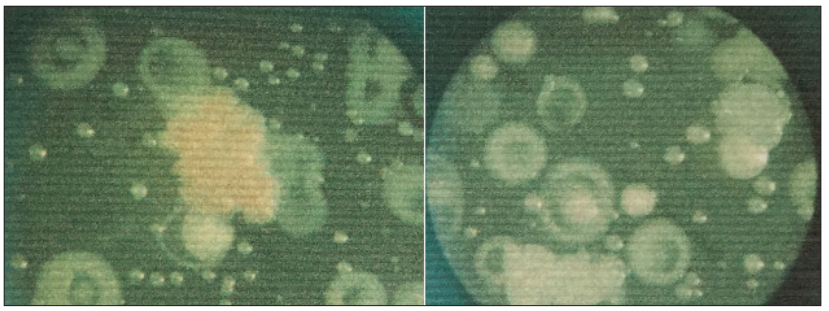

4 pav. Rhodotorula ir Candida genčių mielagrybių kolonijos 


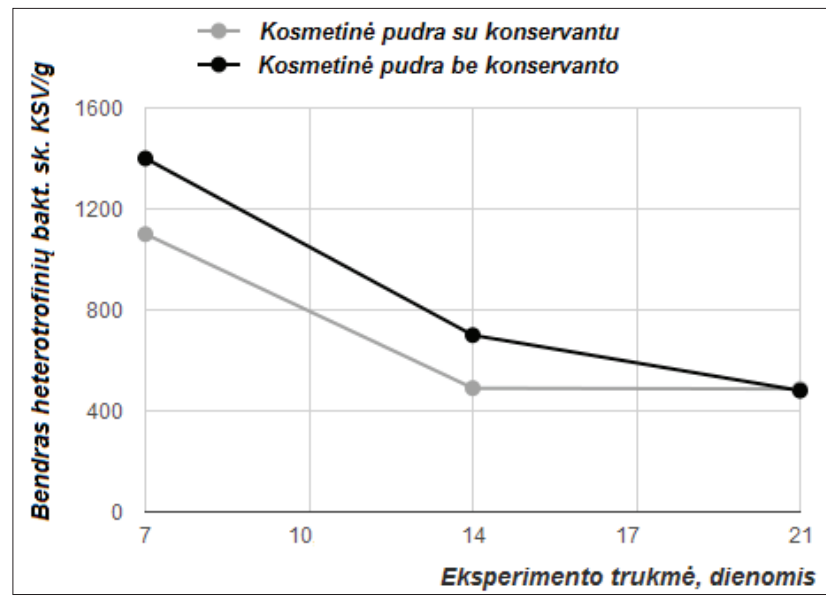

5 pav. Kosmetinių pudrų užterštumo heterotrofinèmis bakterijomis kitimo priklausomybė nuo laiko

KSV/1 g, tačiau neviršijo HN-64-2001 reikalavimų. Iš gautų rezultatų galime teigti, kad mikrobinès ląstelès dauginimuisi trūksta mitybinių medžiagų, kurios reikalingos ląstelès osmosiniam slègiui, citoplazmos koloidinei būsenai palaikyti, taip pat ir biocheminems reakcijoms. Ypač svarbus rodiklis yra mažas drégmès kiekis kosmetinejje pudroje, kuris sutrikdo ląstelių medžiagų apykaitą. Heterotrofinių bakterijų kolonijos, išaugusios agarizuotoje terpejje, pavaizduotos nuotraukose 2 pav.

Pelèsinių ir mielinių grybų kiekis kosmetinèje pudroje. Pelèsiniai grybai ir mielès auga terpèje, kurioje yra polisacharidų ir vandens [12]. Pagal higienos normą HN 64-2001 [11], kosmetinèje pudroje pelèsiniu grybų ir mielių turi nebūti, tačiau mūsų tirtose pudrose šių mikroorganizmų buvo $51 \pm 3 \mathrm{KSV} / 1 \mathrm{~g}$ (pudra be konservuojančios medžagos) ir $19 \pm 1 \mathrm{KSV} / 1 \mathrm{~g}$ (su konservuojančia medžiaga) atitinkamai. Matome, kad kosmetineje pudroje esanti konservuojanti medžiaga pelèsinių grybų ir mielių augimo nesustabdè. Kita vertus, pagal higienos normos reikalavimus šiu grybų kosmetikos gaminyje turètu nebūti, todèl darome prielaidą, kad šių mikroorganizmų galèjo būti kosmetinès pudros žaliavoje arba tyrimo metu šie mikroorganizmai galejo patekti iš aplinkos oro, todèl tam patvirtinti buvo tiriamas laboratorijos oro mikrobinis užterštumas. Mieliagrybių ir pelėsinių grybų kolonijos, išaugusios agarizuotoje terpeje, pateiktos 3 ir 4 pav.

Nustatčius oro mikrobinį užterštumą gavome, kad bendras bakterijų skaičius $48 \mathrm{KSV} / 1 \mathrm{~m}^{3}$ oro, o bendras pelèsinių ir mielinių grybų skaičius $42 \mathrm{KSV} / 1 \mathrm{~m}^{3}$ oro. Gauti tyrimo rezultatai patvirtina, kad kosmetineje pudroje šie grybai galejo patekti iš aplinkos oro.

Konservanto įtaka mikroorganizmams kosmetinėje pudroje. Konservanto paskirtis kosmetineje pudroje yra

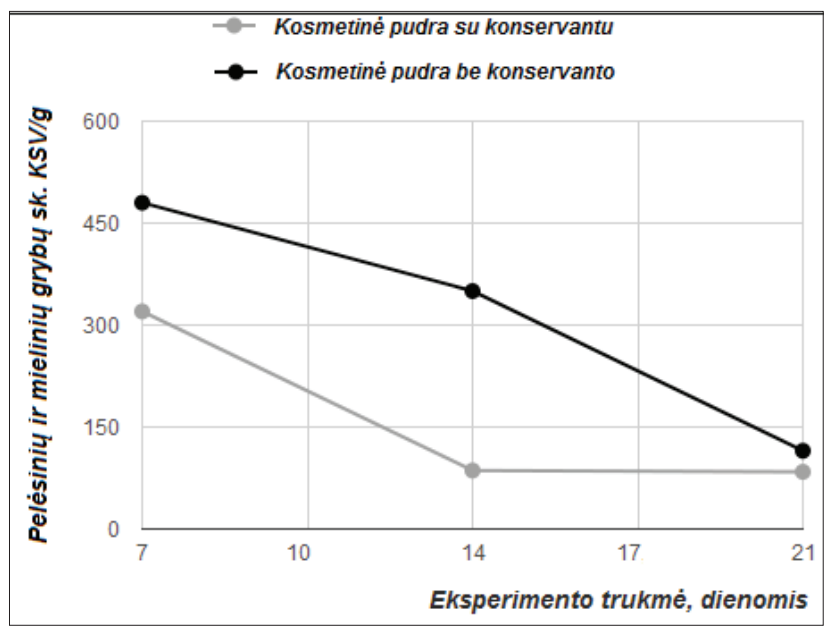

6 pav. Kosmetinių pudrų užterštumo pelèsiniais ir mieliniais grybais priklausomybè nuo laiko

apsaugoti produktą nuo per didelio mikrobinio užterštumo [13]. Eksperimento tikslas - nustatyti konservanto įtaką mikroorganizmo kiekiui, dirbtiniu būdu užteršus kosmetinę pudrą. Tyrimo trukmè buvo 21 diena. Iš tyrimo rezultatų 5-6 pav. matome, kad dirbtinai užkretus kosmetines pudras mikroorganizmais, jų skaičius ženkliai išaugo, tačiau vertinant mikroorganizmų kiekio kitimą pagal laiką, nustateme, kad po 14 dienų mikroorganizmų skaičius pradèjo mažèti. Kita vertus, kosmetinė pudra su konservuojančia medžiaga pasižymejjo mažesniu skaičiumi heterotrofinių bakterijų bei pelèsinių ir mielinių grybų kiekiu. Vertinant mikroorganizmų dauginimąsi po 21 dienos nustateme, kad mikroorganizmų kiekis ženkliai sumažèjo lyginant su pradiniu rezultatu. Vertinant abiejų kosmetinių pudrų mikroorganizmų skaičių po 21 dienos nustatėme, kad nèra reikšmingo skirtumo (5-6 pav.). Šio tyrimo rezultatai patvirtino, kad konservanto poveikis mikroorganizmams neturi reikšmingos įtakos. Todèl galime daryti išvadą, kad konservantai nèra būtini kosmetinejje pudroje, nes mikroorganizmams pudra yra netinkama mitybinè terpé, kadangi joje yra nepakankamai drégmès ir maisto medžiagų.

\section{Išvados}

1. Tirtose kosmetinèse pudrose drègmės kiekis yra mažesnis nei $0,1 \%$, toks drègmès kiekis yra nepakankamas, kad mikroorganizmai galètų daugintis.

2. Nustatyta, kad dirbtinai užteršus pudrą mikroorganizmų kiekis joje palaipsniui mažeja nepriklausomai nuo to, ar pudra su konservuojančia medžiaga, ar be jos.

3. Tinkamai parinkus ingredientus pudra gali tenkinti higienos normos HN 64-2001 reikalavimus net ir nededant ì kosmetinę pudrą konservantų. 


\section{Literatūra}

1. Castanedo-Tardan MP, Zug KA. Patterns of Cosmetic Contact Allergy. Dermatol Clin 2009; 27(3):265-280. http://dx.doi.org/10.1016/j.det.2009.05.014

2. Harvey PW. Parabens, Oestrogenicity, Underarm Cosmetics and Breast Cancer: a Perspective on a Hypothesis. J App Toxicol 2003; 23(5):285-288. http://dx.doi.org/10.1002/jat.946

3. Konduracka E, Krzemieniecki K, Gajos G. Relationship between everyday use cosmetics and female breast cancer. Pol Arch Med Wewn 2014; 124(5):264-9.

4. Lundov MD, Moesby L, Zachariae C, Johansen JD. Contamination versus preservation of cosmetics: a review on legislation, usage, infections, and contact allergy. Contact Derm 2009; 60(2):70-78.

http://dx.doi.org/10.1111/j.1600-0536.2008.01501.x

5. Park ME, Zippin JH. Allergic Conctact Dermatitis to Cosmetics. Dermatol Clin 2014; 32(1):1-11. http://dx.doi.org/10.1016/j.det.2013.09.006

6. Rastogi S, Schouten A, de Kruijf N. et al. Contents of parabens in cosmetic products. Contact Derm 1995; 32: 28-30. http://dx.doi.org/10.1111/j.1600-0536.1995.tb00836.x

7. Davidson P, Taylor T. Chemical Preservatives and Natural Antimicrobial Compounds. In Doyle M, Beuchat L (ed), Food Microbiology: Fundamentals and Frontiers, Third Edition. ASM Press, Washington, DC 2007; 713-745. http://dx.doi.org/10.1128/9781555815912.ch33

8. Maccioni AM, Anchisi C, Sanna A, Sardu C, Dessì S. Preservative systems containing essential oils in cosmetic products. Int J Cosmet Sci 2002; 24(1):53-59. http://dx.doi.org/10.1046/j.0412-5463.2001.00113.x

9. Madigan MM, Martinko J, Parker J. Brock Biology of Microorganisms. 8th ed Upper Saddle River, NJ: Prentice-Hall 2000.

10. Ruiz GM, Rawlings TK, Dobbs FC, Drake LA, Mullady T, Huq A. et al. Global spread of microorganisms by ships. Nat 2000; 408:49-50. http://dx.doi.org/10.1038/35040695

11. Lietuvos higienos normos HN 64-1:2001. Kosmetikos ir asmens higienos gaminiai. Didžiausias leidžiamas mikrobinio užterštumo lygis" http://www3.lrs.1t/pls/inter3/oldsearch.pre ps2?Condition $1=133837 \&$ Condition $2=$

12. Leal JA, Guerrero C, Gómez-Miranda B, Prieto A, Bernabé M. Chemical and structural similarities in wall polysaccharides of some Penicillium, Eupenicillium and Aspergillus species. FEMS Microbiol Lett 1992; 69(2):165-168. http://dx.doi.org/10.1111/j.1574-6968.1992.tb05145.x

13. Lee E, An S, Choi D, Moon S, Chang I. Comparison of objective and sensory skin irritations of several cosmetic preservatives. Contact Derm 2007; 56(3):131-6. http://dx.doi.org/10.1111/j.1600-0536.2007.01001.x

\section{THE NEED OF PRESERVATIVES IN COSMETIC POWDER}

D. Barragan Ferrer, J. M. Barragan Ferrer

Key words: Cosmetic powder, preservatives, the amount of moisture

Summary

Recently, there have been a variety of disputes concerning the possibility that some preservatives might influence cancer development. Following this concern, many assumptions about how to avoid the usage of preservatives when producing some cosmetic products have been discussed. The aim of this research is to determine the necessity of preservatives in cosmetic powder. Few experiments have been performed to estimate the possibility of eliminating the non-preservative cosmetic powder to satisfy the $\mathrm{HN}-64$ requirements of the hygienic standard as same as those that containing preservatives. For this purpose, it was estimated the amount of moisture, the number of microorganisms in the cosmetic powder and the influence of preservative considering the number of microorganisms. After the experiments have been performed, it was confirmed that the proper selection of ingredients, excluding those that can increase the growth of microorganisms, allows avoiding the use of preservatives when producing the cosmetic powder.

Correspondence to: diana.barragan.ferrer@go.kauko.lt

Gauta 2015-09-02 